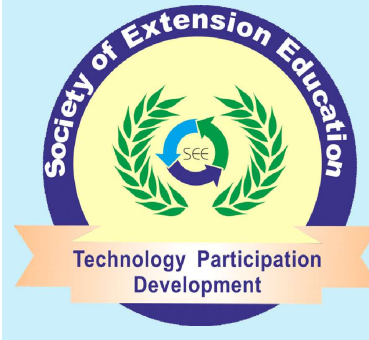

Research Article

\section{Indian Research Journal of Extension Education}

ISSN: 0972-2181 (Print), 0976-1071 (Online)

NAAS Rating : 5.22

Journal homepage: seea.org.in

https://doi.org/10.54986/irjee/2022/jan_mar/97-102

\title{
Nutritional Status of Rural Households: A Case Study in Cooch Behar District of West Bengal
}

\author{
Kaushik Chakroborty ${ }^{1}$, Deb Sankar Gupta ${ }^{2}$ and Prasenjit Pal ${ }^{3}$
}

1. PG student (Ag. Stat.), 2. Prof. (Ag. Stat.), UBKVV, Pundibari, Cooch Behar, 3. Asst. Prof. (ESS), College of Fisheries, CAU (I), Lembucherra, Tripura

Corresponding authore-mail :gupta_ubkv@rediffmail.com

Paper Received on October 05, 2021, Accepted on December 21, 2021 and Published Online on January 01,2022

\begin{abstract}
The present work focuses on studying the effect of socio-economic factors on nutritional status of rural households under the Coochbehar-II block of Coochbehar district in West Bengal. A well-structured interview schedule was prepared to collect information about the socio-economic status and nutritional status of the respondents. As an indicator of Nutritional status, the Body Mass Index (BMI) values of the respondents were studied. In the present study, the Independent-Samples Kruskal-Wallis Test and Independent-Samples Mann-Whitney U Test (non-paramedic test) were employed to study the effect of different socio-economic variables on nutritional status of the respondents. Age of the respondents, educational qualification of the respondents, Family size, and House type of the respondents were found to significantly affect the BMI scores of the respondents. The categories of the significantly contributing variables for nutrition like age, education, and house type show significant associations with the BMI categories using Contingency table and Chi-square test.
\end{abstract}

Keywords: Nutritional status; Body Mass Index; Non-paramedic test; Contingency table.

$\mathbf{N}$ utrition is a primary necessity for health, and health is one of every human being's fundamental rights (Devadas, 1951). The science of food and its connection to health is called human nutrition. It is the process through which chemical components in food are absorbed by body tissues, giving energy to the body for performing physical and mental activities that are part of everyday life (Weininger et al., 2020). Nutrients are chemical components present in food that help the human body stay nourished. Nutritional status represents the fulfilment of the human body's nutritional and protective needs, as reflected in physical, physiological, and biochemical features, function, and health status (Gurinovice et al., 2017).
According to the National Family Health Survey, 2019-20 for the state of West Bengal, 34.4 per cent of children under the age of five are stunted, 20.4 per cent are wasted, 33.5 per cent are underweight, and 3.6 per cent are overweight in rural regions. In rural areas, 17.4 per cent of women and 16.8 per cent of men have a BMI which is below normal. Obesity affects around 20.3 per cent of women and 14.5 per cent of men. Under the Coochbehar district, 28.7 per cent of children under the age of five are stunted, $16.8 \%$ are wasted, 22.5 per cent are underweight, and 2.3 per cent are overweight. Among adults, 18.1 per cent of women have a BMI that is below normal, and 16.5 per cent are obese. Body Mass Index (BMI) is a common weight-for-height index 
that is used to categorise people as underweight, normal, overweight, or obese. An individual's BMI value is found out by dividing the weight in kilograms by the square of the height in meters. BMI is one of the widely accepted nutritional status indicators for adults (James et al., 1988; Ferro-Luzzi et al., 1992; Naidu and Rao, 1994). In Indian society, social factors are the main factors influencing nutritional status (Upadhyay and Tripathi, 2017). According to the National Centre for Educational Statistics (2008), socio-economic status is a complete combined assessment of an individual's or family's sociological and economic level, indicating their socio-economic position in comparison to others based on education, employment, and income. A person's or a family's socioeconomic position is a major determinant of their health and nutritional condition. Socio-economic conditions also affect the food habit, food availability, and amount of food consumption of an individual or within a family or household. This, in turn, has an impact on household food security.

\section{METHODOLOGY}

The present work focuses on the objective of studying the effect of socio-economic status on the nutritional status of rural households under the Coochbehar-II block of Coochbehar district in West Bengal. Three-stage sampling without replacement design is used for the selection of households. In the first stage, 3 Gram Panchayats are selected by random sampling without replacement from among 13 Gram Panchayats under the Block. The 3 Gram Panchayats Pundibari, Madhupur, and Dhangdhinguri are the firststage or primary sampling units. In the second stage, from each of the 3 G.P., 3 villages are selected randomly without replacement. From Pundibari G.P. 3 villages Kalarayer Kuthi, Sajerpar Ghoramara, and Hoglabari are selected. From Madhupur G.P. 3 villages Petbhata Chandan Chowraha, Haripur, and Jaggna Narayaner Kuthi are selected. From Dhandhingguri G.P. Dharmaborer kuthi, Holonger kuthi, and Basantapur are the selected villages. These 9 villages are the secondary or second-stage sampling units. In the third stage, from each of the selected villages 7 households are selected randomly without replacement. Total 63 households are selected in the third stage of sampling and they are the tertiary or third-stage sampling units. The head of the household is the respondent for our study. A well- structured interview schedule was prepared to take into consideration the objectives of the study. Data was collected by visiting the selected households and interacting with the respondents. For studying the nutritional status, BMI values are calculated. The weight of the respondents was measured using a weighing machine and height was taken using a measuring tape. The Body Mass Index (BMI) value for each respondent was calculated by dividing their weight $(\mathrm{kg})$ by the square of their height $(\mathrm{m})$. They were classified into three categories of BMI based on their BMI value by utilizing the following scale: Underweight $-<18$, Normal - 18-25, Overweight - 25-39. Information regarding socio-economic status was collected by taking into consideration the variables such as age, gender, income, education, occupation, landholding, house type, family type, and family size. The collected data were processed and tabulated for statistical analysis.

In the present study, the independent-samples Kruskal-Wallis test and independent-samples MannWhitney U Test (non-paramedic test) were employed to study the effect of different socio-economic variables on nutritional status of the respondents. The frequency table and chi-square contingency tests were also applied to the dataset. The results have been analysed statistically by using SPSS (Statistical Package for the Social Sciences) Software.

\section{RESULTS AND DISCUSSION}

Status of anthropometric measurements : The status of height, weight and Body mass index (BMI) of the respondents participated in the study was presented in terms of gender. They are tabulated in the following tables. Table 1 indicates that the mean BMI for the respondents is $22.94 \mathrm{Kg} / \mathrm{m}^{2}, 22.81 \mathrm{~kg} / \mathrm{m}^{2}$ for males and and is more $\left(23.43 \mathrm{~kg} / \mathrm{m}^{2}\right)$ for females. The mean height and weight for males is $162 \mathrm{~cm}$ and $59.78 \mathrm{~kg}$; for females, the mean height and weight are $150 \mathrm{~cm}$ and $54 \mathrm{~kg}$. It also indicates that overall 68.25 per cent of the respondents are having normal BMI, 4.76 per cent are underweight and 26.98 per cent are overweight. Among males, 68 per cent are normal, 6 per cent are underweight and 26 per cent are overweight. 69.23 per cent of the females are normal and 30.76 per cent are overweight.

Status of socio-personal variable: The status of sociopersonal variables of the respondents participated in the 
Table 1. Height, weight and BMI of respondents

\begin{tabular}{llll}
\hline Measurements & Overall & Male & Female \\
\hline Mean height $(\mathrm{cm})$ & 159 & 162 & 150 \\
Mean weight $(\mathrm{kg})$ & 58.58 & 59.78 & 54 \\
Mean BMI $\left(\mathrm{Kg} / \mathrm{m}^{2}\right)$ & 22.94 & 22.81 & 23.43 \\
BMI category & Male & Female & Total \\
Underweight & $3(6 \%)$ & 0 & $3(4.76 \%)$ \\
Normal & $34(68 \%)$ & $9(69.23 \%)$ & $43(68.25 \%)$ \\
Overweight & $13(26 \%)$ & $4(30.76 \%)$ & $17(26.98 \%)$ \\
Total & 50 & 13 & 63 \\
\hline
\end{tabular}

study are found out and tabulated in the per centage of observations that exist under each category of the variables are mentioned in the following tables. Table 2, indicates that out of 63 respondents who participated in the study, $41(65.1 \%)$ respondents are having their age between 28-54 years and 13 (20.6\%) respondents are having age more than 54 years and $9(14.3 \%)$ respondents are having age of less than 28 years. It also indicates that out of 63 respondents who participated in the study, 50 (79.4\%) are male Table 2 indicates that out of 63 respondents who participated in the study, 15 $(23.81 \%)$ have family sizes of $<3,36(57.14 \%)$ have family sizes of 3 and 5 , while, $12(19.05 \%)$ have a family size $>7$. Out of 63 respondents who participated in the study, 27 (42.9\%) are qualified to primary level, 9 $(14.3 \%)$ of them are qualified to the middle school level, $9(14.3 \%)$ can only read and write. $6(9.5 \%)$ of them are qualified to the high school level,6 $(9.5 \%)$ can read only while $5(7.9 \%)$ are graduates. Only $1(1.6 \%)$ respondent is illiterate. Table 2 also reflects that out of 63 respondents who participated in the study, $23(36.5 \%)$ are cultivators, $21(33.3 \%)$ are labourers, $10(15.9 \%)$ are having business as their occupation, $8(12.7 \%)$ are engaged in service while only $1(1.65)$ respondent have an independent occupation. Table 2 also indicates that out of 63 respondents who participated in the study, 40 $(63.5 \%)$ are having a Gross monthly income of more than Rs.5000, 22 (34.9\%) are having a Gross monthly income within the range of Rs. 2001-Rs. 5000 while only $1(1.6 \%)$ respondent is having an income of less than Rs. 2000. Out of 63 respondents who participated in the study, 27 (42.9\%) are living in a mixed house, 22 $(34.9 \%)$ are living in a pucca house, $10(15.9 \%)$ are living in a kutcha house while 4 (6.3\%) are living in a hut.

Results on Kruskal-Wallis test and Mann-Whiteney $U$ Test : The two non-parametric tests viz. KruskalWallis test and Mann-Whitney U Test were applied to
Table 2. Distribution of respondents among various age groups $(\mathrm{N}=63)$

\begin{tabular}{|c|c|c|}
\hline Profile & No. & $\%$ \\
\hline \multicolumn{3}{|l|}{ Age group } \\
\hline$<28$ & 9 & 14.3 \\
\hline $28-54$ & 41 & 65.1 \\
\hline$>54$ & 13 & 20.6 \\
\hline \multicolumn{3}{|l|}{ Gender } \\
\hline Male & 50 & 79.4 \\
\hline Female & 13 & 20.6 \\
\hline \multicolumn{3}{|l|}{ Family Size } \\
\hline$<3$ & 15 & 23.81 \\
\hline $3.00-5.00$ & 36 & 57.14 \\
\hline$>5$ & 12 & 19.05 \\
\hline \multicolumn{3}{|c|}{ Educational qualification } \\
\hline Illiterate & 1 & 1.6 \\
\hline Can Read Only & 6 & 9.5 \\
\hline Read And Write & 9 & 14.3 \\
\hline Primary & 27 & 42.9 \\
\hline Middle & 9 & 14.3 \\
\hline High School & 6 & 9.5 \\
\hline Graduate & 5 & 7.9 \\
\hline \multicolumn{3}{|l|}{ Occupation } \\
\hline Labourer & 21 & 33.3 \\
\hline Business & 10 & 15.9 \\
\hline Independent & 1 & 1.6 \\
\hline Cultivation & 23 & 36.5 \\
\hline Service & 8 & 12.7 \\
\hline \multicolumn{3}{|l|}{ Income group } \\
\hline$<2000$ & 1 & 1.6 \\
\hline 2001 to 5000 & 22 & 34.9 \\
\hline$>5000$ & 40 & 63.5 \\
\hline \multicolumn{3}{|l|}{ House type } \\
\hline Hut & 4 & 6.3 \\
\hline Kutca house & 10 & 15.9 \\
\hline Mixed & 27 & 42.9 \\
\hline Pucca & 22 & 34.9 \\
\hline
\end{tabular}

study (Table 3) the effect of different independent variables on the BMI score of the respondents. The independent variables and the test used are listed as follows: According to the results of the IndependentSamples Kruskal-Wallis Test and Independent-Samples Mann-Whitney U Test, the variables - age of the respondents, educational qualification of the respondents, family size, and house type of the respondents were found to significantly affect the BMI scores of the respondents. Whereas, the variables occupation, income, family type, landholding category, and gender 
failed to significantly affect the BMI scores of the respondents. The BMI scores were also not found to be significantly affected by difference in residence of Gram Panchayats.

Table 3. Results of non-parametric test used for different variables

\begin{tabular}{lcc}
\hline Variables & Test performed & Level of significance \\
\hline Age & ISKWT & $0.013^{*}$ \\
Occupation & ISKWT & 0.115 \\
Income & IISKWT & 0.072 \\
Education & ISKWT & $0.036^{*}$ \\
Family type & ISMWUT & 0.209 \\
House type & ISKWT & $0.029^{*}$ \\
Landholding & ISKWT & 0.246 \\
Family size & ISKWT & $0.043^{*}$ \\
Gender & ISMWUT & 0.470 \\
Gram Panchayat & ISKWT & 0.644 \\
\hline
\end{tabular}

*Significance at $5 \%$ level of significance;

ISKWT $=$ Independent-Samples Kruskal-Wallis Test

ISMWUT $=$ Independent-Samples Mann Whitney U Test

BMI category and Age of respondents : The contingency table was found out for the different levels of the age of the respondents with different BMI categories ( 1 for Underweight, 2 for Normal weight, and 3 for Overweight) to check the correspondence between the categories of these two variables. Then the chi-square test was used to check the significance between the associations of the two variables.

Table 4. Contingency table between Body Mass Index (BMI) category and age of the respondents

\begin{tabular}{|c|c|c|c|c|}
\hline \multicolumn{5}{|c|}{ Age ( years) category } \\
\hline BMI category & $<28$ & $28-54$ & $>54$ & Total \\
\hline 1 (Under weight) & 2 & 1 & 0 & 3 \\
\hline 2 (Normal weight) & 5 & 26 & 12 & 43 \\
\hline 3 (Over weight) & 2 & 14 & 1 & 17 \\
\hline Total & 9 & 41 & 13 & 63 \\
\hline
\end{tabular}

Table 4 indicates that among 63 respondents in the age group 28 years, 3.17 per cent of individuals are underweight, 7.9 per cent of individuals have a normal BMI and 3.17 per cent are overweight. For the age group of $28-54$ years, only $1.6 \%$ of individuals are underweight, 41.2 per cent are normal and 22.2 per cent are overweight. The problem of being underweight is not recorded for the age group $>54$ years, as 19 per cent of individuals are normal and only 1.6 per cent are overweight.
Table 5. Chi-square tests of the above contingency table between BMI category and age of the respondents

\begin{tabular}{lccc}
\hline Test & Value & df & Asymptotic sig. (2-sided) \\
\hline Chi-square & 10.949 & 4 & $0.027^{*}$ \\
\hline
\end{tabular}

*Significant at $5 \%$ level of significance

The Chi-square test was used to check the significance between the association of the two variables and it was found that the chi-square test was significant at 5 per cent level of significance which implies that there is an association between BMI category and age group of respondents.

BMI category and Educational qualification: The contingency Table 5 was found out for the different Educational level of the respondents with different BMI categories (1 for Underweight, 2 for Normal weight, and 3 for overweight) to check the correspondence between these two variables. Then the chi-square test was used to check the significance between the associations of the two variables.

Table 6. Contingency table between Body Mass Index (BMI) category and educational qualification of the respondents

\begin{tabular}{lllllllll}
\hline \multicolumn{10}{c}{ Educational qualification } \\
BMI category & 1 & 2 & 3 & 4 & 5 & 6 & 7 & Total \\
\hline 1 (Underweight) & 0 & 2 & 0 & 1 & 0 & 0 & 0 & 3 \\
2 (Normal) & 1 & 3 & 5 & 20 & 8 & 5 & 1 & 43 \\
3 (Overweight) & 0 & 1 & 4 & 6 & 1 & 1 & 4 & 17 \\
Total & 1 & 6 & 9 & 27 & 9 & 6 & 5 & 63 \\
\hline
\end{tabular}

(Various educational categories are: 1-illiterate, 2-can read only, 3-read and write, 4-primary, 5-middle, 6-high school, 7-graduate.)

Table 6 indicates that among 63 respondents, 9.5 per cent of individuals who are overweight are educated to primary level. For graduates and for those who can only read and write, 6.34 per cent of individuals are overweight. 3.17 per cent of individuals who can only read are underweight and $1.6 \%$ of individuals educated to primary level are underweight. The majority of individuals having normal BMI are seen among those having qualifications at primary level (31.7\%), middle school level (12.6\%) and high school level (7.9\%).

Table 7. Chi-square Tests of the above contingency table between BMI category and educational qualification of the respondents

\begin{tabular}{lccc}
\hline Test & Value & df & Asymptotic sig. (2-sided) \\
\hline Chii-square & 23.067 & 12 & $0.027^{*}$
\end{tabular}

Significant at $5 \%$ level of significance 
The chi-square test was used to check the significance between the association of the two variables and it was found that the chi-square test was significant at 5 per cent level of significance which implies that there is an association between the BMI categories and educational qualification categories of the respondents (Table 7).

BMI category and family size: The contingency table was found out for the different family size of the respondents with the 3 BMI categories ( 1 for Underweight, 2 for Normal weight, and 3 for Overweight) to check the correspondence between these two variables. Then the Chi-square test was used to check the significance between the association of the two variables.

Table 8. Contingency Table between Body Mass Index (BMI) category and family size of the respondents

\begin{tabular}{|c|c|c|c|c|c|c|c|c|c|c|c|}
\hline \multicolumn{12}{|c|}{ Family size (Fs) } \\
\hline BMI & 2 & 3 & 4 & 5 & 6 & 7 & 8 & 11 & 12 & 14 & Total \\
\hline 1 & 0 & 1 & 1 & 1 & 0 & 0 & 0 & 0 & 0 & 0 & 3 \\
\hline 2 & 0 & 11 & 14 & 11 & 1 & 4 & 0 & 0 & 1 & 1 & 43 \\
\hline 3 & 1 & 2 & 7 & 2 & 2 & 1 & 1 & 1 & 0 & 0 & 17 \\
\hline Total & 1 & 14 & 22 & 14 & 3 & 5 & 1 & 1 & 1 & 1 & 63 \\
\hline
\end{tabular}

(Fs - Family size; BMI categories : 1- Underweight, 2- Normal, 3- Overweight)

Table 8 shows that among 63 respondents, 15.8 per cent of individuals are overweight, 3.17 per cent are underweight and 39.6 per cent of individuals show normal BMI when the family size is two, three or four. 11.11 per cent overweight is seen among those having a family size of four.7.9 per cent overweight is seen in people having a family size of five, six, or seven, while 25.3 per cent of individuals show normal BMI.

Table 9. Chi-square tests of the above contingency table between BMI category and family size of the respondents

\begin{tabular}{lccc}
\hline Test & Value & df & Asymptotic sig. (2-sided) \\
\hline Chi-square & 21.105 & 22 & 0.514 \\
\hline
\end{tabular}

(*Significant at $5 \%$ level of significance

The chi-square test was used to check the significance between the association of the two variables and it was found that the Chi-square test was not significant at $5 \%$ level of significance which implies that there is lack of association between BMI category and family size of the respondents (Table 9).

BMI category and house type: The contingency table was found out for the different house type of the respondents with the 3 BMI categories (1 for Underweight, 2 for Normal weight, and 3 for Overweight) to check the correspondence between these two variables. Then the chi-square test was used to check the significance between the associations of the two variables.

Table 10. Contingency table between BMI category and House type of the respondents

\begin{tabular}{lccccc}
\hline BMI category & Hut & Kutcha & Mixed & Pucca & Total \\
\hline 1(Underweight) & 0 & 1 & 0 & 2 & 3 \\
2(Normal) & 2 & 7 & 24 & 10 & 43 \\
3 (Overweight) & 2 & 2 & 3 & 10 & 17 \\
Total & 4 & 10 & 27 & 22 & 63 \\
\hline
\end{tabular}

Table 10 indicates that among 63 respondents, majority $(15.8 \%)$ of the overweight individuals live in pucca house, follow ed by mixed house (4.7\%), kutcha house and Hut (3.1\% each). 3.1 individuals live in pucca house and are underweight, while 1.6 per cent individual living in kutcha house are underweight. 38 per cent people living in mixed house show normal BMI, followed by pucca house (15.8\%), Kutcha house (11.1\%) and hut $(3.1 \%)$. House type is associated with maintenance of hygiene, house space and living condition cumulatively acting as an indirect factor for affecting BMI

Table 11. Chi-Square tests of the above contingency table between BMI category and house type of the respondents

\begin{tabular}{lccc}
\hline Test & Value & df & Asymptotic sig. (2-sided) \\
\hline Pearson chi-square & 12.746 & 6 & $0.047^{*}$
\end{tabular}

*Significant at $5 \%$ level of significance

The chi-square test was used to check the significance between the association of the two variables and it was found that the chi-square test was significant at 5 per cent level of significance which implies that there is an association between BMI category and house type of respondents (Table 11).

Table 12. Association of BMI category with variables

\begin{tabular}{lll}
\hline Variables & $X^{2}$ value & p-value \\
\hline Age & 10.949 & $0.027^{*}$ \\
Education & 23.067 & $0.027^{*}$ \\
Family size & 21.105 & 0.514 \\
House type & 12.746 & $0.047^{*}$ \\
\hline
\end{tabular}

*Significant at $5 \%$ level of significance

Contingency tables were constructed for the different categories of age of the respondents, educational qualification, family size, and house type with 
the three BMI categories, underweight, normal, and overweight. Pearsonian chi-square test results show that among the 4 variables, age, education and house type show significant associations with the BMI categories. Whereas, family size was not able to show any significant association with the BMI categories (Table 12).

\section{CONCLUSION}

Underweight was most prevalent among those individuals aged less than 28 years, and those having minimal or no education at all. Low BMI values were recorded for individuals having a family size of three to five members. The prevalence of overweight was maximum among those aged between 28-54 years and for those having educational qualifications from primary level to graduation. People living in pucca houses recorded higher BMI values as compared to those living in huts, kutcha houses, or mixed houses. Although overweight was prevalent among those having a family size of three to five, maximum overweight individuals are also seen among those having a family size of two to six members. This can be attributed to different resource and food allocation patterns existent in different households. Well-educated people and people having a better house type show higher BMI values, while those with low educational qualifications show the problem of being underweight. Higher socioeconomic status is associated with a higher risk of being underweight, while low socioeconomic status may lead to the problem of being underweight. Hence, it is suggested to make awareness among the people regarding the intake of nutritious food and balance diet, importance of Psychical exercise and proper maintenance of hygiene for helping to keep the body and environment healthy and clean.

\section{CONFLICTS OF INTEREST}

The authors declare that they have no conflicts of interest.

\section{REFERENCES}

Devadas, R.P. (1951). Role of nutrition in human well-being (a study of south Indian diets). Proc. $4^{\text {th }}$ Annual meeting of Indian Conference of Social Work. pp. 97-104. Indian Conference of Social Work, Madras, India.

Ferro-Luzzi, A.; Sette, S.; Franklin, M. and James, W.P. (1992). A simplified approach of assessing adult chronic energy deficiency. European J. Clin. Nutr. 46 (3) :173-186.

Gurinoviæ, M.; Zekoviæ, M.; Mileševiæ, J.; Nikoliæ, M. and and Glibetiæ, M. (2017). Nutritional assessment. Reference Module in Food Science. Elsevier Inc, Amsterdam.

James, W.P.; Ferro-Luzzi, A. and Waterlow, J.C. (1988). Definition of chronic energy deficiency in adults. Report of a working party of the international dietary energy consultative group. European J. Clin. Nutr. 42 (12) : 969-981.

Naidu, A.N. and Rao, N.P. (1994). Body Mass Index: A measure of the nutritional status in Indian populations. Eur. J. Clin. Nutr. 1994 Nov; 48 Suppl 3:S131-40. https://pubmed.ncbi.nlm.nih.gov/7843150/

Upadhyay, R. and Tripathi, K.D. (2017). How can we assess the nutritional status of an individual? J.Nutr. Food Sci., 7 (6) : 640.

Weininger, J.; Kent-Jones, D.W.; Carpenter, K. and Truswell, A.S. (2020). Human nutrition. Encyclopedia Britannica, 9 Aug. 2021, https://www.britannica.com/science/human-nutrition. Accessed 1 October 2021. https://globalnutritionreport.org/ resources/nutrition-profiles/asia/southern-asia/india/

https://en.wikipedia.org/wiki/Socioeconomic_status 